\title{
Analysis of Characteristics and Turbulent Mixing of Seawater Mass in Lombok Strait
}

\author{
Amir Yarkhasy Yuliardi1*, Agus S. Atmadipoera2 ${ }^{2}$, Gentio Harsono ${ }^{3}$, \\ Nyoman Metta N. Natih², Kentaro Ando 4 \\ ${ }^{1}$ Master Program of Marine Science, IPB University \\ ${ }^{2}$ Department of Marine Science and Technology, IPB University \\ Jl. Raya Dramaga, Babakan, Kec. Dramaga, Bogor, Jawa Barat 16680 Indonesia \\ ${ }^{3}$ Faculty of Defence Strategy, Indonesian Defence University \\ Kawasan IPSC Sentul, Sukahati, Kec. Citeureup, Bogor, Jawa Barat 16810 Indonesia \\ 4 Japan Agency for Marine-Earth Science and Technology, JAMSTEC \\ 2-15, Natsushima, Yokosuka, Kanagawa zip:237-0061, Japan \\ Email: amiryarkhasy@gmail.com
}

\begin{abstract}
The Lombok Strait, as one of the outlet straits, is part of the ITF route, which is directly adjacent to the Indian Ocean. There is a sill in the Lombok Strait, which is a place for internal wave generation. Leg-1 data from the Japan Agency for Marine-Earth Science and Technology in collaboration with the Agency for the Assessment and Application of Technology which is part of the Tropical Ocean Climate Study Expedition including CTD Yoyo and ADCP taken using ship vehicles R/V Kaiyo. CTD Snapshot from PUSHIDROSAL using the KRI Spica 934 vehicle part of the Opssurta Baruna Jaya 2 Expedition. Determination of seawater mass stratification with the criteria for the thermocline layer is $\geq 0.05^{\circ} \mathrm{C} . \mathrm{m}^{-1}$. Four types of water masses were identified, Java Sea, mixed seawater mass (Java Sea - ITF) which occurred diapycnal mixing, North Pacific Subtropical Water (NPSW) and North Pacific Intermediate Water (NPIW). The seawater mass stratification in the Lombok Strait based on temperature, salinity and density which are seen to follow the internal tidal pattern. The average values for energy dissipation and vertical diffusivity for each layer and replication were $5.73 \times 10^{-7} \mathrm{~W} . \mathrm{Kg}^{-1}$ and $3.67 \times 10^{-2} \mathrm{~m}^{2} \cdot \mathrm{s}^{-1}$ for CTD Yoyo and $2.25 \times 10^{-6} \mathrm{~W}^{\mathrm{Kg}} \mathrm{gg}^{-1}$ and $7.38 \times 10^{-2}$ $\mathrm{m}^{2} . \mathrm{s}^{-1}$ for CTD Snapshot. The value obtained is greater than the open ocean and straits in other studies. The high shear value confirms this in the thermocline layer. The Richardson gradient value $>0.25$ is relatively constant in the thermocline layer.
\end{abstract}

Keywords: turbulent mixing, seawater mass, Lombok strait, ITF, internal wave, CTD, Yoyo retrieval

\section{Introduction}

Indonesian waters have an important influence on the global climate. Indonesia is the hub of the thermohaline circulation conveyor belt line or better known as Indonesia Throughflow (ITF). The water mass from the Pacific Ocean enters Indonesian waters through two routes. The western route carries the water mass of the northern Pacific Ocean through the Mindanao Strait moving into the Sulawesi Sea then into the Makassar Strait. Exiting the Makassar Strait, it is divided into two parts, some to the Flores Sea then to the Banda Sea and then the other half directly to the Indian Ocean via the Lombok Strait (Wyrtki, 1961). The west route is the main route that carries around $11.6 \mathrm{~Sv}\left(1 \mathrm{~Sv}=10^{6} \mathrm{~m}^{3} . \mathrm{s}^{-1}\right)$ from the annual 3-year mean varies from 6 to $16 \mathrm{~Sv}$. (Gordon et al., 2010)

Atmadipoera and Hasanah (2017) explains that the circulation pattern in the western part of the
Flores Sea is characterized by two unique current areas, namely the strong ITF Flores current axis flowing southwestward towards the Lombok Strait, and anti-cyclonic eddy currents in the Southern Hemisphere in the Bali Sea. The ITF Flores branching occurs north off the coast of Lombok, where one branch of the current $-2.92( \pm 0.94)$ Sv flows towards the Lombok Strait and the other branch continues to the east of the Flores Sea. The Lombok Strait is one of the ITF exits, which is directly influenced by various phenomena of atmosphere-oceanic interactions that have an impact on water mass conditions in the Lombok Strait. There are also internal waves generated in the Lombok Strait sill area. There are three distinct patterns of internal wave propagation in the Lombok Strait: only to the south, only to the north, and in both directions. It is closely related to ITF, stratification, and tidal conditions as a control for internal wave formation and the direction of propagation in the Lombok Strait region (Susanto et al., 2005).
*) Corresponding author

(C) IImu Kelautan, UNDIP 
The Lombok Strait is possible to become an area of transition or transformation from water masses originating from the Pacific Ocean to the Indian Ocean. The local topographic configuration and sill in the middle of the strait and the turbulence of the flow are thought to trigger water mass mixing, which results in the transformation of the water mass. Until now, several related studies have been conducted including the INSTANT expedition in 20032005. Water mass research conducted so far in Indonesia has not yet calculated the intensity of turbulent mixing which is thought to be able to modify the water mass characters of NPSW and NPIW entering through this strait.

\section{Materials and Methods}

This research was conducted using data in the Lombok Strait on March 5 - 62009 for 12 hours with a Yoyo retrieval configuration and September 21 2016 with a snapshot taking configuration and in the Pacific Ocean obtained from World Ocean data (WOD) on February 22, 2009 (Figure 1). The data used in this study include Conductifity-Temperatur-Depth (CTD), Acoustic Doppler Current Profilers (ADCP) and Tides. CTD Yoyo is Leg-1 data from the Japan Agency for Marine-Earth Science and Technology (JAMSTEC) in collaboration with the Agency for the Assessment and Application of Technology (BPPT) which is part of the Tropical Ocean Climate Study (TOCS) Expedition including CTD and ADCP (Shipboard-ADCP and Lowered-ADCP) taken using ship vehicles R/V Kaiyo.
CTD Snapshot from PUSHIDROSAL using the KRI Spica 934 vehicle and part of the Opssurta Baruna Jaya 2 Expedition. Tide data in the Lombok Strait can be obtained from the Geospatial Information Agency (BIG) (http://tides.big.go.id/), TPX09-atlas (https://www.tpxo.net/global/tpxo9-atlas), $\quad$ FESO4 (https://www.aviso.altimetry.fr/) and the Intergovernmental Oceanographic Commission of UNESCO (IOC) (http://www.ioc-sealevelmonitoring. org/). The tidal data used are hourly time series data which are adjusted to the CTD data recording period. Data on the Pacific Ocean is obtained from World Ocean Database (WOD) can be accessed at https://www.ncei.noaa.gov.

CTD Yoyo data over a 12 hour period received 27 replications. Current measurements were carried out using Acoustic Doppler Current Profilers (ADCP) with an acoustic frequency of $38 \mathrm{kHz}$ from Teledyne RD Instruments, which was installed on R/V Kaiyo. This data has been processed with LTA data and using CODAS (Common Oceanographic Data Access System) software, developed by the University of Hawaii. The measuring depth of the L-ADCP is 1213 $\mathrm{m}$ and data was used to a depth of $589 \mathrm{~m}$ in this study. The S-ADCP measures back and forth between Bali Island and Lombok Island to a maximum depth of $1117 \mathrm{~m}$. CTD data from the Baruna Jaya 2 expedition contained 4 collection points in the middle of the Lombok Strait. Each point has a take data with different depths depending on the bathymetry at the location of collection. The maximum depth used in this study is $600 \mathrm{~m}$.

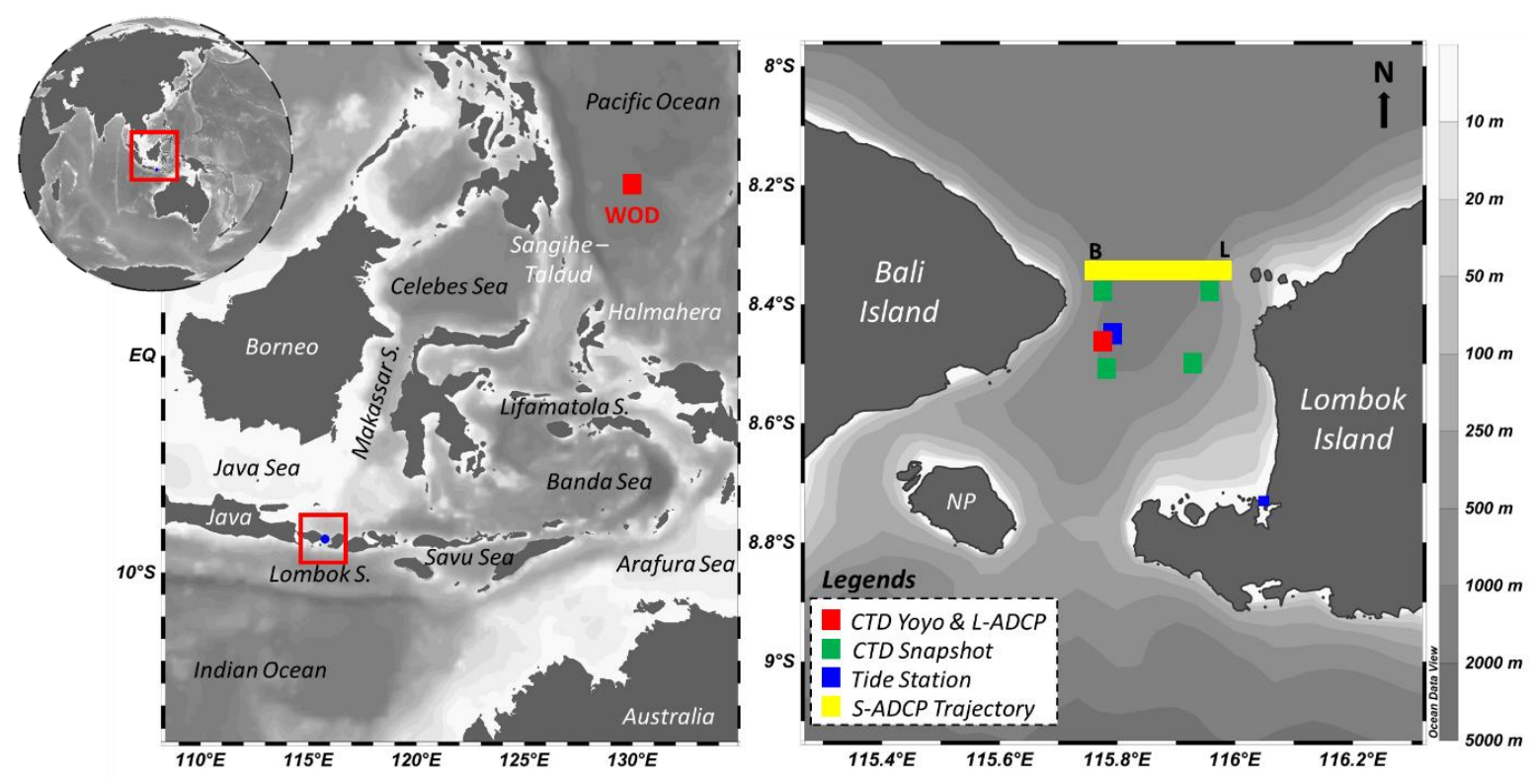

Figure 1. Location of CTD Yoyo \& L-ADCP concurrent collection with a difference of 1-3 minutes (red dot), CTD snapshot performed on the same date (green dot), tidal data with location at the Yoyo \& L-ADCP CTD collection point and port Lembar in the same time period (blue dot) and S-ADCP data back and forth 4 times Lombok-Bali (yellow line) to the right of the map. CTD data obtained from the WOD (white dot) on the left of the map. 
The criteria for distinguishing the three layers are usually using a temperature threshold or using a temperature vertical gradient. In this study, the criteria used are gradient based. Hao et al., (2012) stated that the thermocline layer when the temperature vertical gradient is more than $0.05^{\circ} \mathrm{C} . \mathrm{m}^{-}$ 1. Potential temperature data (obtained from in situ data) and salinity are used to identify the mass of water using the T-S (Temperature-Salinity) diagram where the mass of water originates (Emery and Thomson 1998). This analysis is instrumental and is able to provide the best explanation for identifying seawater types, namely the mass of water with a specific temperature and salinity value. Mixing process occurs when fluid conditions are unstable. The brunt vaisala frequency $(N)$ is used to identify a fluid stability:

$$
N^{2}=-\frac{g d p}{\rho_{0} d z}
$$

Where $g$ is the acceleration due to gravity $\left(9.8 \mathrm{~m} . \mathrm{s}^{-2}\right)$, $\rho_{0}$ is the background density or the average density of the measurement results (kg. $\left.{ }^{-3}\right)$. Thorpe (1977) measured the temperature profile in lake waters and found a dynamic instability or overturn. The first step is to determine the Thorpe Displacement $(T d)$ (Dillon, 1982):

$$
T d=z a-z b
$$

Where $z a$ and $z b$ are the initial pressure positions and the pressure after repetition respectively. The identified $T d$ was validated by the water mass test from Galbraith and Kelly (1996), which is commonly called the GK test. The threshold used is 0.7 to minimize the GK test rejecting some real overturn, which is usually a small overturn area (Stanfield et al., 2001). Only turbulent patches that have a close relationship between $\rho$, T and $S$ are considered valid.

Dillon (1982) confirmed that in ocean waters, this instability is related to turbulent dissipation, which is then used to estimate the vertical diffusivity coefficient. Thus, Thorpe displacement is especially useful for describing the vertical range of a mixture.

$$
L_{T}=\left(\frac{1}{n} \sum_{i=1}^{n} T d_{i}^{2}\right)^{\frac{1}{2}}
$$

Where $T d$ is the Thorpe displacement at depth and is the number of samples over the depth range. In stratified fluids, a fluid parcel that moves in a vertical distance to convert all its kinetic energy into potential energy can be expressed by the Ozmidov scale (Park et al., 2008):

$$
L_{o}=\left(\frac{\varepsilon}{N^{3}}\right)^{\frac{1}{2}}
$$

Where $\varepsilon$ is the dissipation of turbulent kinetic energy per unit mass. The determination of the dissipation of turbulent kinetic energy is used to describe the amount of kinetic energy that is lost or its shape changes in the water. The calculation of the amount of kinetic energy that undergoes a dissipation process based on the Ozmidov scale is:

$$
\varepsilon=L_{o}^{2} N^{3}
$$

Where $L o$ denote the Ozmidov length scale. Turbulent vertical diffusivity values at each depth are then obtained by applying:

$$
K_{z}=\frac{\gamma \varepsilon}{N^{2}}
$$

Where $\gamma$ denotes mixing efficiency. In this study, a value of 0.2 was used, which has referred to the calculations made by previous studies. The calculation results of turbulent intensity in waters $0.193 \pm 0.007,0.191 \pm 0.013,0.192 \pm 0.010$, and $0.182 \pm 0.021$ for depths of $50-300 \mathrm{~m}, 300-500 \mathrm{~m}$, $500-800 \mathrm{~m}$ and $800-2000 \mathrm{~m}$, so that the value of 0.2 is comparable with empirical estimates (Purwandana et al., 2020).

The chance for turbulence to occur is smaller in conditions of strong water stratification so that a greater turbulent energy is needed to counter the large vertical gradient of density (Fer et al., 2004). The dynamics of water mass mixing in a stably stratified layer is regulated by vertical current shear as the basis of the buoyant flow (Martinez et al. 2006).

$$
S^{2}=\frac{\partial u^{2}}{\partial z}+\frac{\partial v^{2}}{\partial z}
$$

Where the variables $u$ and $v$ are the zonal and meridional component currents $\left(m s^{-1}\right)$. However, the presence of friction dissipation with the layer's underneath will deplete the energy of the stratified turbulence component. Estimation and quantification of water mass characteristics and the likelihood of turbulence are obtained from the Richardson (Ri) gradient number (Kitade et al., 2003):

$$
R i=\frac{N^{2}}{S^{2}}
$$

The Richardson gradient $(\mathrm{Ri})$ describes the relative magnitude of the forces that stabilize the density stratification against the stability of the shear (Delpeche et al., 2010).

\section{Results and Discussion}

\section{Vertical profiles of temperature, salinity, and density}

The water mass layering in the Lombok Strait has a visualized pattern through vertical profiles of temperature, salinity, and density (Figure 2) obtained 

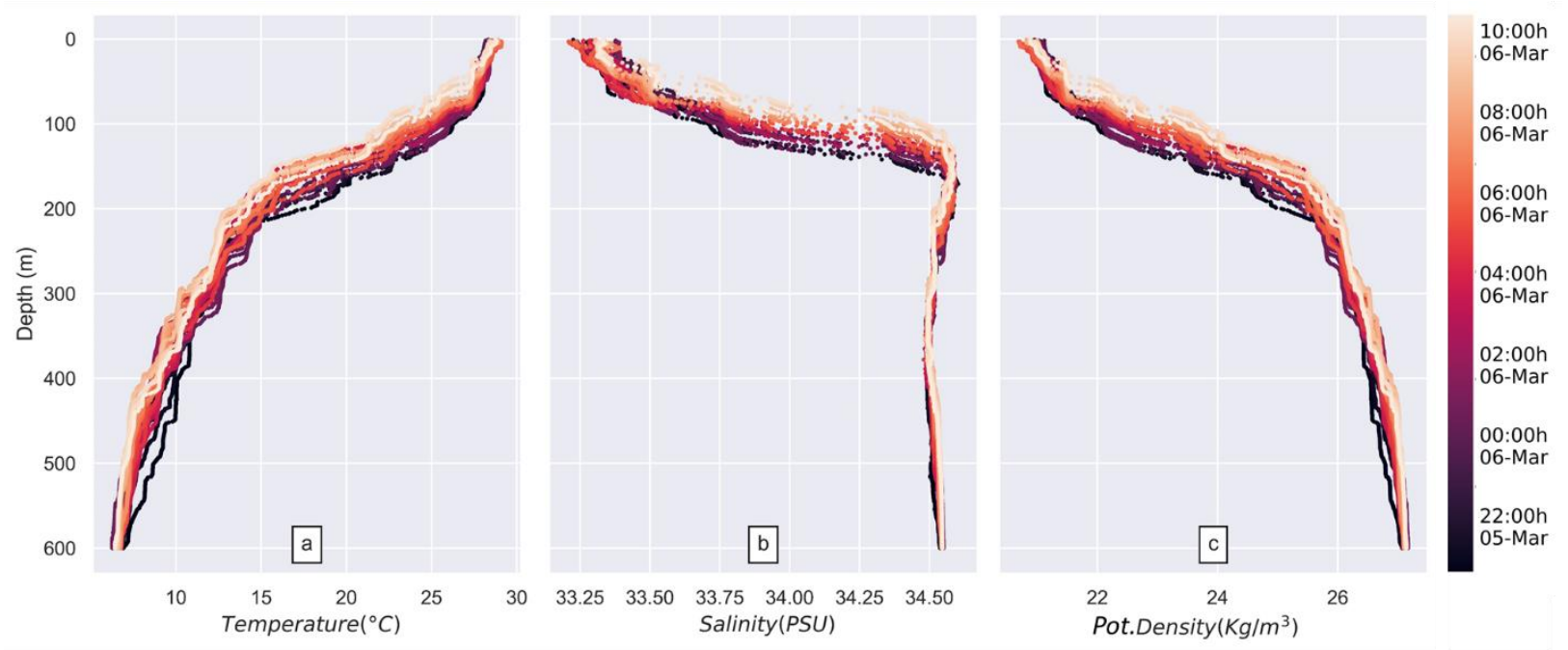

Figure 2. Vertical profile (a) temperature, (b) salinity and (c) density on repetitions of 1 - 27 CTD Yoyo cast with a period of 12 hours at a depth of $0-600 \mathrm{~m}$.

from all replications of data collection. It was seen that there was an increase in water mass which was quite evident at each CTD cast. In the first to last cast, the pattern tends to be the same but at a different depth. This increase in water mass is visible in the thermocline layer and is related to the tidal pattern that occurs when taking CTD data. The vertical temperature profile shows the maximum value in the surface layer and tends to be homogeneous. The thermocline layer fluctuates and has decreased drastically, while the deep layer is relatively homogeneous. The temperature layer has a pattern that can be seen from the vertical temperature profile in the Lombok Strait waters and is divided into three layers, namely the mixed layer (homogeneous layer), the thermocline layer and the deep layer.

The upper and lower limits of the thermocline layer can be seen in Figure 3. The deep layer is a layer with relatively homogeneous temperature characteristics and experiencing a slight temperature decrease. Determination of the water column layer based on the temperature gradient $(\Delta T)$ (Hao et al., 2012). The mixed layer occurs because of the stirring caused by wind friction so that the temperature is relatively homogeneous and has a high-temperature value because it is in the surface layer that is directly exposed to the sun (Steward, 2002). Categorized as a thermocline layer if the value vertical gradient temperature more than $0.05^{\circ} \mathrm{C} \cdot \mathrm{m}^{-1}$. The thermocline layer is the layer between the mixed layer and the deep layer. This layer shows a drastic decrease in temperature with respect to depth.

The upper and lower limits of the thermocline layer show a difference in the pattern between the temperature, salinity, and density values. The profiles of temperature, salinity and density on the mixed layer depth line and the thermocline depth line can be seen in Figure 4. In the mixed layer depth line, the temperature, salinity, and density lines are the same, the temperature decreases in value with respect to depth, while the density and salinity have different values increases with depth. In the thermocline depth line, it appears to have a different pattern. Temperature and density have the same pattern, the temperature value decreases with depth, while the density increases with increasing depth. However, the salinity value shows a different pattern, and the salinity value decreases because this layer is indicated as the boundary between the NPSW water mass which is characterized by maximum salinity and the NPIW water mass which has low salinity characteristics. So that in this layer, the salinity value decreases, before then it rises again when it passes through the NPIW water mass layer.

The cross-distribution of temperature, salinity and density values repeatedly during CTD data collection $(12 \mathrm{~h})$ represents a tidal period. The distribution profile has water mass layer characteristics which generally follow the tidal pattern. The transverse profiles of temperature, salinity and density can be seen in Figures 5 . The temperature value decreases with increasing depth, and for the salinity value, there is an increase in the thermocline layer. Combined temperature and salinity stratification patterns are indicated by density stratification. The result of the cross-sectional temperature shows a slight difference in isothermal thickness which can be caused by tidal influence. In the thermocline layer (43-249 m), there was a drastic decrease in temperature. The isothermal line (27$14^{\circ} \mathrm{C}$ ) was seen 
Table 1. Water mass characteristics of the Lombok Strait

\begin{tabular}{ccccc}
\hline \multirow{2}{*}{$\begin{array}{c}\text { Type of Water } \\
\text { Mass }\end{array}$} & Depth $(\mathrm{m})$ & \multicolumn{3}{c}{ Characteristic of Water Mass } \\
\cline { 3 - 5 } & & Temperature $\left({ }^{\circ} \mathrm{C}\right)$ & Salinity $(\mathrm{psu})$ & Density $\left(\mathrm{kg} \cdot \mathrm{m}^{-3}\right)$ \\
\hline Java Sea & $1-50$ & $29.11-27.29$ & $33.2-33.54$ & $20.69-21.5$ \\
Java Sea - ITF & $56-101$ & $25.81-23.45$ & $33.75-34.24$ & $22.16-23.21$ \\
NPSW & $111-239$ & $21.52-14.2$ & $34.53-34.6$ & $24.01-25.8$ \\
NPIW & $283-388$ & $11.29-8.89$ & $34.47-34.5$ & $26.35-26.75$ \\
\hline
\end{tabular}

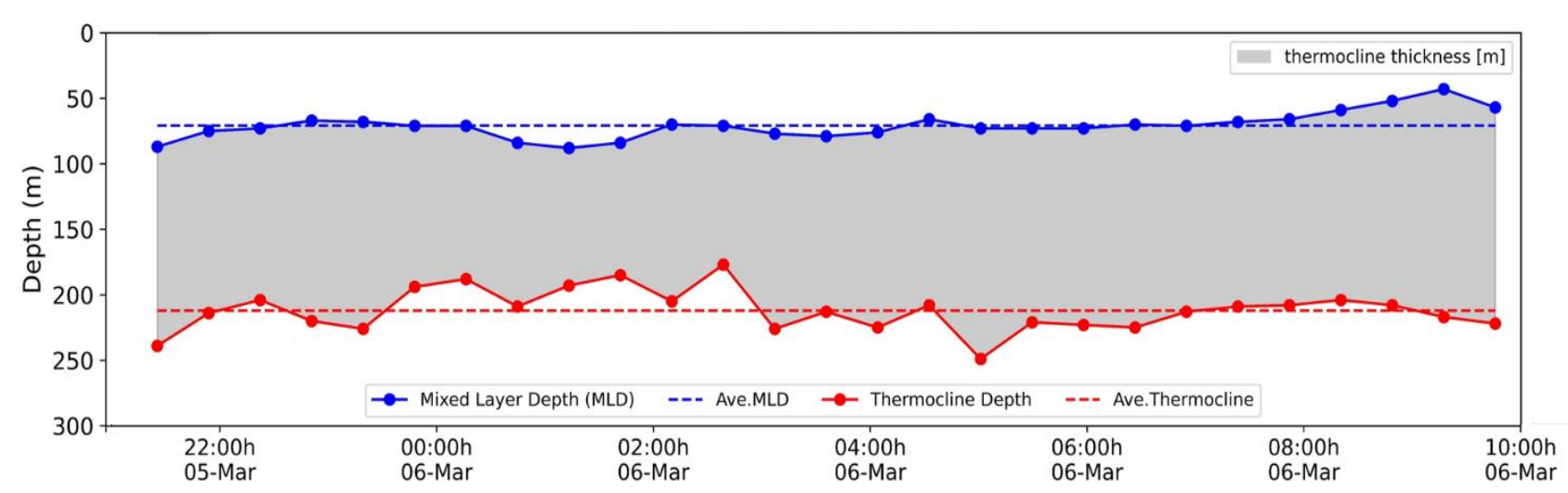

Figure 3. Stratification profile in the Lombok Strait during CTD Yoyo cast. The solid blue line represents the depth limit of the mixed layer and the mean value of the dashed blue line. The red line shows the depth limit of the thermocline and the mean value by the dashed red line. The thickness of the thermocline layer between the two boundaries is gray.

which formed a line towards the tide seen in the isothermal line in replications 1-27 Yoyo. In the deep layer, there was a change in temperature but not as sharp as in the thermocline layer. The results of the cross-sectional density show a slight difference in thickness which can be caused by tidal influence. Density values form a combination of temperature and salinity stratification patterns indicated by density stratification vary from 20.5 - $27.3 \mathrm{~kg} \cdot \mathrm{m}^{-3}$.

\section{Characteristic of water mass}

The characteristics of the water mass passing through the Lombok Strait waters can be seen through the T-S diagram, as shown in Figure 6. Information on the type of water mass, depth and water mass characteristics can be seen in Table 1. The surface layer is dominated by water masses from the Makassar Strait moving southward and then entering the Lombok Strait. In the transition season, the water masses around the Java Sea originate from the South China Sea and the Makassar Strait (Siregar et al., 2017)

Atmadipoera et al. (2009) mention that the surface layer to the thermocline layer shows a freshening of salinity caused by excessive rainfall in the Java Sea moving eastward. Furthermore, below the water mass of the Java Sea, it is seen that the mixed water mass between the Java Sea, which is characterized by low salinity and ITF, which is characterized by high salinity. This occurs because the southern waters of the Lombok Strait are the meeting place for the Java Sea and the ITF route that flows from the Makassar Strait. The mixing that occurs is in the form of diapycnal mixing, which is the transfer of the water mass property (salinity and temperature) followed by a decrease in the isopycnal line. The NPSW water mass has a salinity value that is more saline the water mass found below it. In the lower thermocline layer, a water mass with minimal salinity was found, which was assumed to be the NPIW water mass. The Lombok Strait is a place for internal tides to emerge and has the potential to become a place for the transformation of water masses.

Nagai et al. (2017) obtained results through non-hydrostatic research that the breaking of internal waves caused vertical mixing in the ITF in Indonesian waters. The NPSW and NPIW water masses are part of the global water masses that flow through the ITF and experience changes in character when they reach the Lombok Strait. A decrease in salinity values is seen when compared to the inlet in the Sulawesi Sea and the Lifamatola Passage with a value reaching 35.2 psu in the eastern monsoon (Gunawan et al., 2019). In this study, there was a significant decrease in S-Max reaching 0.25 psu at the WOD data observation point in the western Pacific Ocean and CTD Yoyo in the Lombok Strait. 


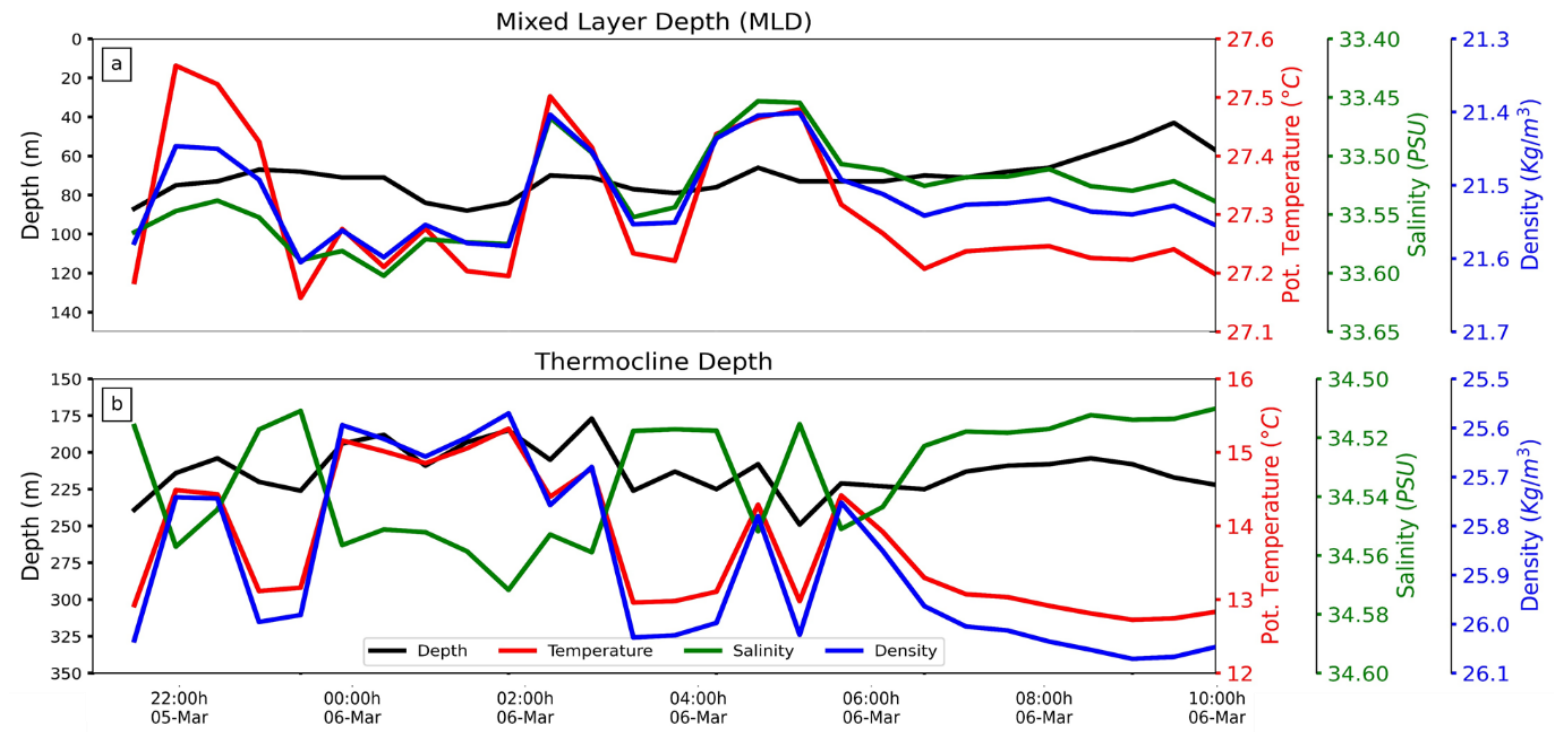

Figure 4. The temperature, salinity and density profiles during the Yoyo CTD cast were at (a) the mixed layer depth line and (b) the thermocline depth line. Black line for depth, red line for temperature, green line for salinity and blue line for density.

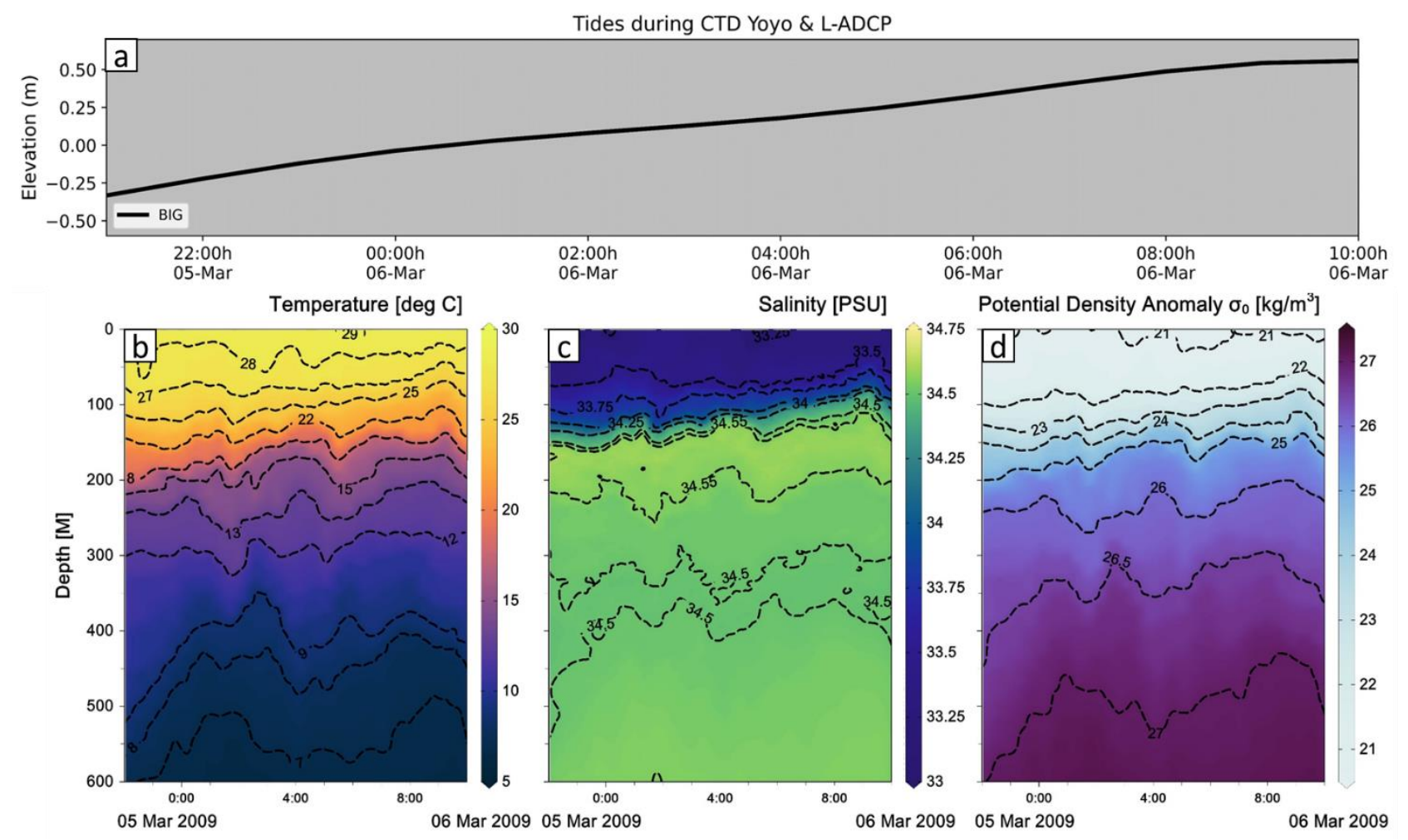

Figure 5. Profiles of (a) tidal elevation, distribution of the cross section against time in replicates 1- 27 CTD Yoyo cast of (b) temperature, (c) salinity and (d) density over a 12 hour period.

\section{Analysis of vertical turbulent mixing}

The mixing of the water masses can be caused by an unstable water column which can be identified by calculating the Brunt Vaisala Frequency value. The results of the calculation of the $N^{2}$ value for all Yoyo CTD replications in the waters of the Lombok Strait can be seen in Figure 7(a). The mixed layer in replicates 1-27 had an $\mathrm{N}^{2}$ value ranging from 0 $3.65 \times 10^{-4}$ with an average of $9.27 \times 10^{-5}$. It can be said 


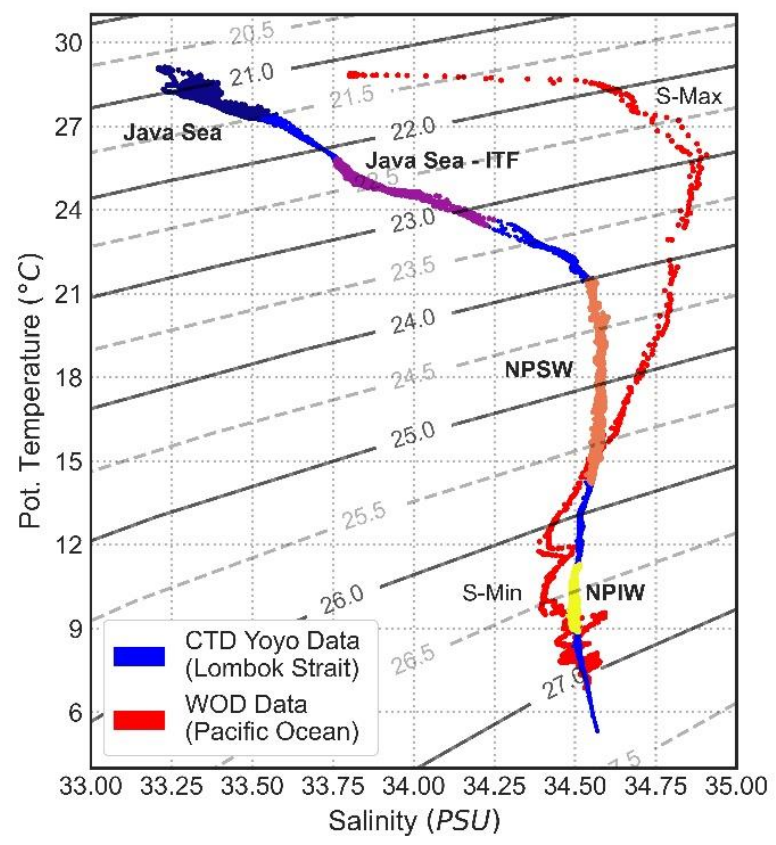

Figure 6. TS diagram of Lombok Strait (blue) with type of water mass; Java Sea in navy, Java Sea-ITF in purple, NPSW in orange, NPIW in yellow and Pacific Ocean (red) with maximum and minimum salinity.

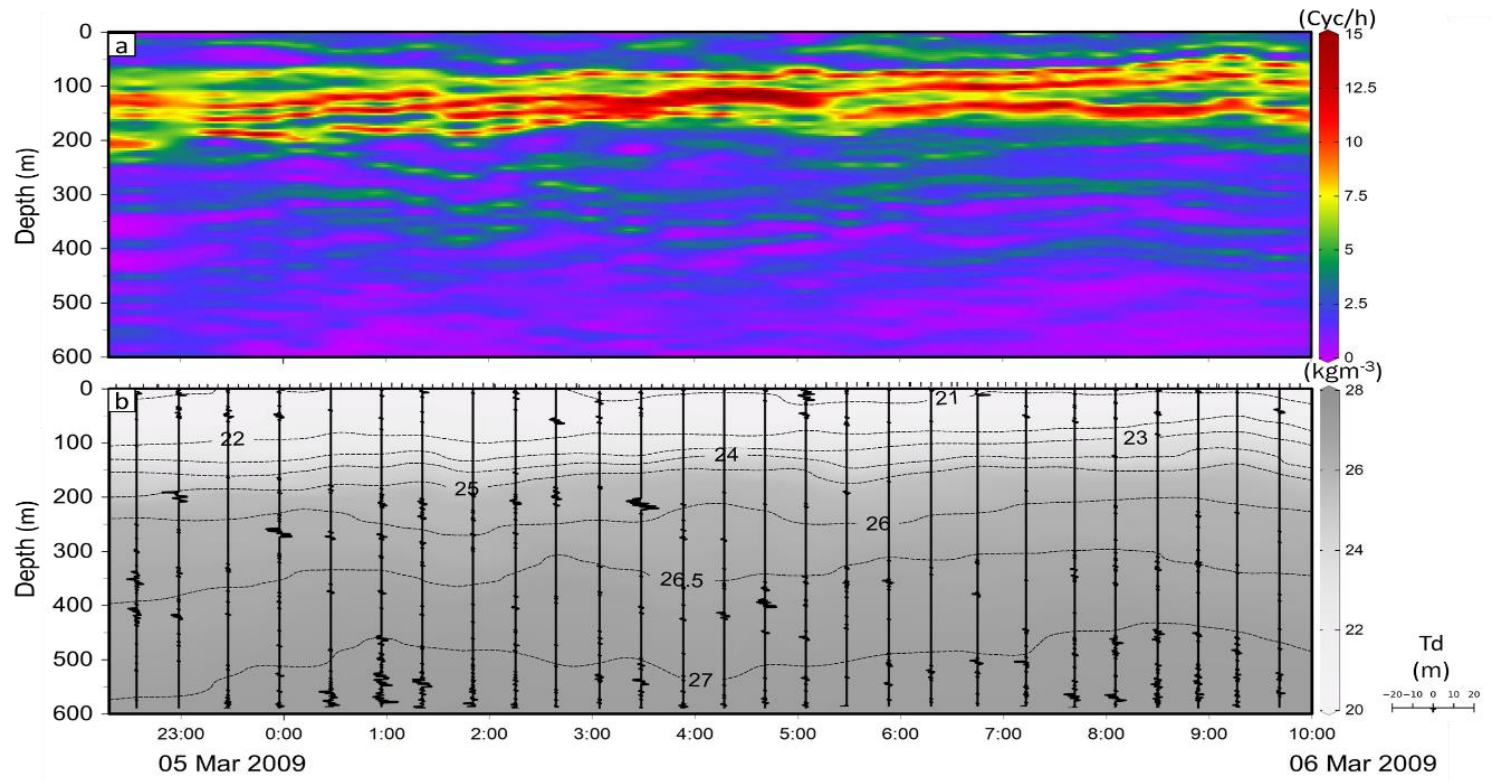

Figure 7. The cross-sectional versus time distribution in replicates 1- 27 CTD Yoyo cast of (a) brunt vaisala and (b) density overlaid with Thorpe displacement (black line) on the scale at the bottom right.

that the mixed layer has a low-density vertical gradient value so that the water mass is less stable, which can lead to vertical mixing (Pond and Pickard 1983). The $N^{2}$ value increased sharply in the thermocline layer, which had the highest $\mathrm{N}^{2}$ value compared to the mixed layer and the deep layer. The thermocline layer in replicates 1 - 27 has an $N^{2}$ value ranging from $0-1.55 \times 10^{-3}$, with an average of $2.49 \times 10^{-4}$. This indicates that the thermocline layer is relatively more stable than the mixed layer and the deep layer. The high $N^{2}$ value in the thermocline layer is because there is a pycnocline layer which is a layer where the density gradient increases sharply with respect to depth (Pond and Pickard 1983). In the deep layer, casts 1 - 27 have an $N^{2}$ value ranging from $0-1.42 \times 10^{-4}$ with an average of $3.17 \times 10^{-5}$. The low $N^{2}$ value indicates that the deep layer is unstable and prone to turbulence or vertical mixing. It is stated that the higher the $\mathrm{N}^{2}$ value in a layer, the greater the static stability of the low-density water mass above 
the high-density water mass of the layer, conversely, if the $\mathrm{N}^{2}$ value is lower, the water column is less stable or is in a state of static instability.

The mix layer had a $T d$ value ranging from $-7 \mathrm{~m}$ to $12 \mathrm{~m}$, with a minimum $\mathrm{Td}$ value on the 16th replication and a maximum on the 20th cast. The $T d$ value in the mixed layer is thought to be related to the wind speed blowing on the surface of the water. The thermocline layer has the lowest $T d$ value compared to the mixed layer and the deep layer. The $T d$ value in the thermocline layer ranges from $-3 \mathrm{~m}$ to $2 \mathrm{~m}$. The smallest $T d$ value was found in the 23rd replication, and the greatest was in the 9th and 24th replications. The thermocline layer is the layer that has the highest level of static stability compared to the mixed layer and the deep layer. So, it has a small $T d$ range. The seams are in the Td value range of $-14 \mathrm{~m}$ to $16 \mathrm{~m}$. The highest $\mathrm{Td}$ value was found in the 6 th cast and the smallest in the 1st cast. The low value of the static stability of the water mass in the deep layer makes the $T d$ value large. Thorpe scale $(L T)$ calculation to see turbulent vertical mixing is obtained from the results of Thorpe Displacement $(T d)$. Thorpe scale describes how much water mass reversal occurs.

The profile of the energy dissipation range and vertical diffusivity in depth can be seen in Figure 8. Thorpe analysis method is only able to detect the value of kinetic energy dissipation up to 0 (10-11 W.Kg1) (Galbraith and Kelley 1996). The results of the calculations that have been obtained are made an average every $50 \mathrm{~m}$ depth. The value of the kinetic energy dissipation $(\varepsilon)$ describes the turbulent active layer that experiences energy dissipation or breaking into smaller forms. The vertical structure of the tubulent mixture is important as one of the factors in parameterizing the existence of tidal mixing (St. Laurent et al., 2002). The modified water mass structure in the mixing process is indicated by the high energy dissipation value. The energy dissipation profile has a value range of $0\left(10^{-8}-10^{-5} \mathrm{~W} . \mathrm{Kg}^{-1}\right)$, and the vertical diffusivity profile is in the range of 0 values $\left(10^{-6}-10^{0} \mathrm{~m}^{2} \cdot \mathrm{s}^{-1}\right)$. The range of energy dissipation values appears to widen at a depth of 0 $250 \mathrm{~m}$, then the value weakens, and the value range is also getting shorter at a depth of $250 \mathrm{~m}$ and below. In the thermocline layer, which is a stable layer, a greater amount of energy is needed to distort or disturb the stability, so that mixing occurs. The value of the dissipation value is in accordance with the numerical study conducted by Nagai and Hibiya (2015) which obtained results $\varepsilon>10^{-6} \mathrm{WKg}^{-1}$ in narrow straits.

The mean and standard deviation values for each layer $(50 \mathrm{~m})$ can be seen in Figure 9. In this study, it was found that the vertical diffusivity value in the thermocline layer was lower when compared to other layers. Because the thermocline layer is more stable, the water mass property dissipation rate is smaller than the mixed layer, and the deep layer is more unstable. The value of vertical diffusivity in the Lombok Strait, when compared to other studies, is still quite high. The average values for energy dissipation and vertical diffusivity for each layer and replication were $5.73 \times 10^{-7} \mathrm{~W} . \mathrm{Kg}^{-1}$ and $3.67 \times 10^{-2}$ $\mathrm{m}^{2} . \mathrm{s}^{-1}$ for CTD Yoyo and $2.25 \times 10^{-6} \mathrm{~W} . \mathrm{Kg}^{-1}$ and $7.38 \mathrm{x}$ $10^{-2} \mathrm{~m}^{2} . \mathrm{s}^{-1}$ for CTD Snapshot. The mean value is obtained from the sum of all ctd yoyo repetitions and all points for ctd snapshot. The kinetic energy in the turbulent flow that is dissipated to transfer energy to the deep layer has a low energy dissipation value indicating that less energy is needed. The high turbulent kinetic energy dissipation in the mixed layer is an indication of the amount of energy required to transform the mass of water in a layer. Previous research by Hatayama (2004) at Ambang Dewakang sill (south of Makassar Strait) from simulation results that reached $6 \times 10^{-3} \mathrm{~m}^{2} . \mathrm{s}^{-1}$, Purwandana et al. (2014) in the north of the Alor Strait it reaches $10^{-3} \mathrm{~m}^{2} . \mathrm{s}^{-1}$ and Nagai et al. (2021) reaches $10^{-2} \mathrm{~m}^{2} \cdot \mathrm{s}^{-1}$ in a narrow tidal strait.

\section{Tidal dynamics}

The fluctuation of tidal predictions in the waters of the Lombok Strait shows a mixed semidiurnal tidal pattern (mixed tide tends to double daily) and can be seen in Figure 10 (a). There are three data models (BIG, FES, TPX09) and one tidal station (IOC) direct measurement data located at Sheet Harbor showing the same pattern. The pattern of S-ADCP data collection can be seen in Figure 10 (b). The pattern when S-ADCP data collection shows the condition of tide is going down. In comparison, Figure 10 (c) is an enlargement of the tide prediction when taking CTD and L-ADCP data which shows the conditions leading to the tide and has been confirmed according to the transverse distribution pattern of the temperature, salinity, and density values.

Robertson and Ffield (2005) state that Indonesian waters are generally dominated by $\mathrm{M} 2$ internal tides (semidiurnal) with a period of 12.42 hours. The M2 tide enters from the Indian Ocean through the Timor Sea and partly through the Lombok Strait. Data collection for S-ADCP and CTD Yoyo and L-ADCP each took measurements for 12 hours. In this measurement, there is no visible pattern of one wave period. The field measurement data at the Sheet Harbor tide measurement station shows this pattern, but it is not very visible. However, the data model where the sampling point is right at the data collection point is no longer visible. This is because at the time of taking data on the monthly phase of the moon, which results in a weak tidal power. In addition, because the model data has undergone a smoothing 


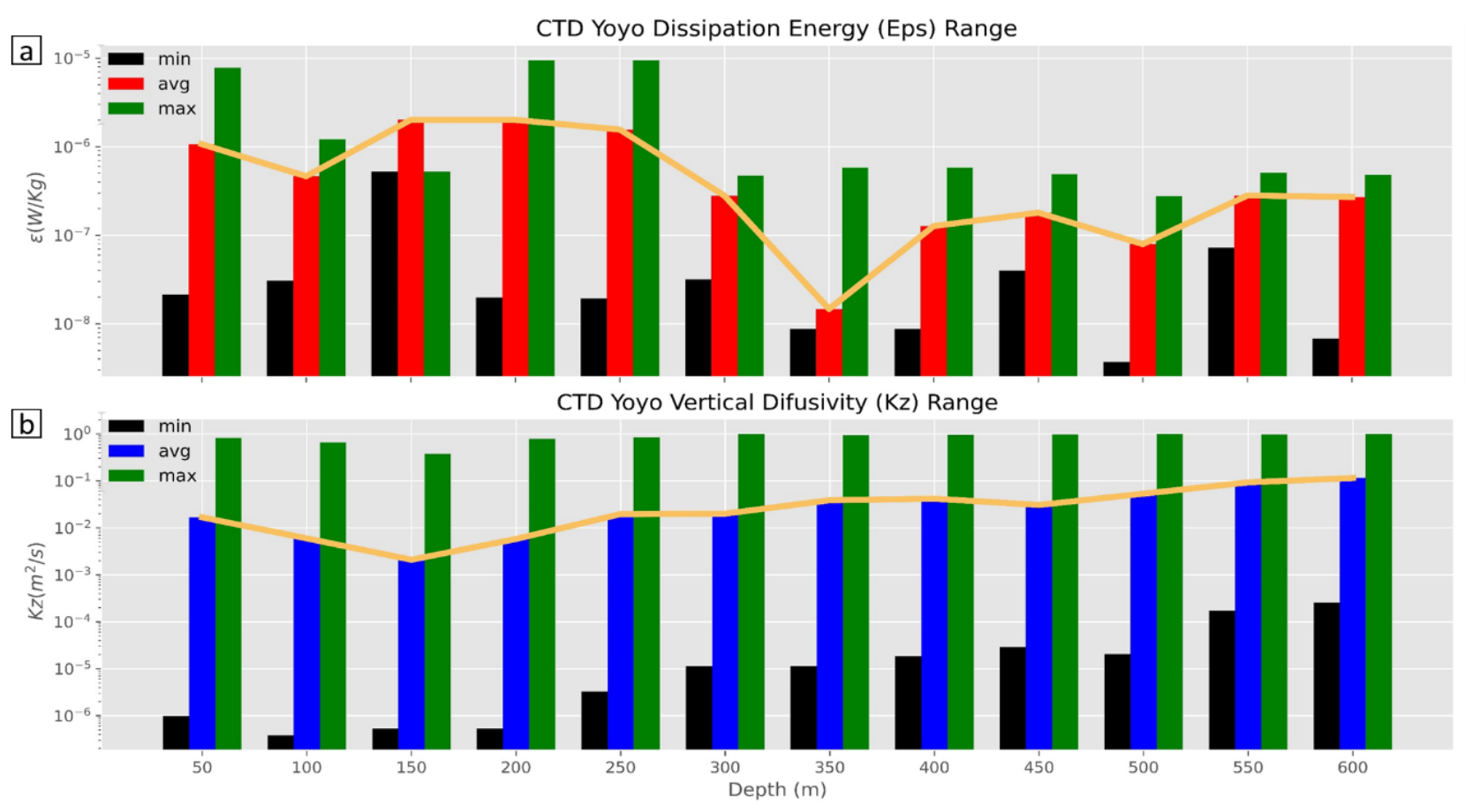

Figure 8. Range of values (a) energy dissipation and (b) vertical diffusivity CTD Yoyo cast
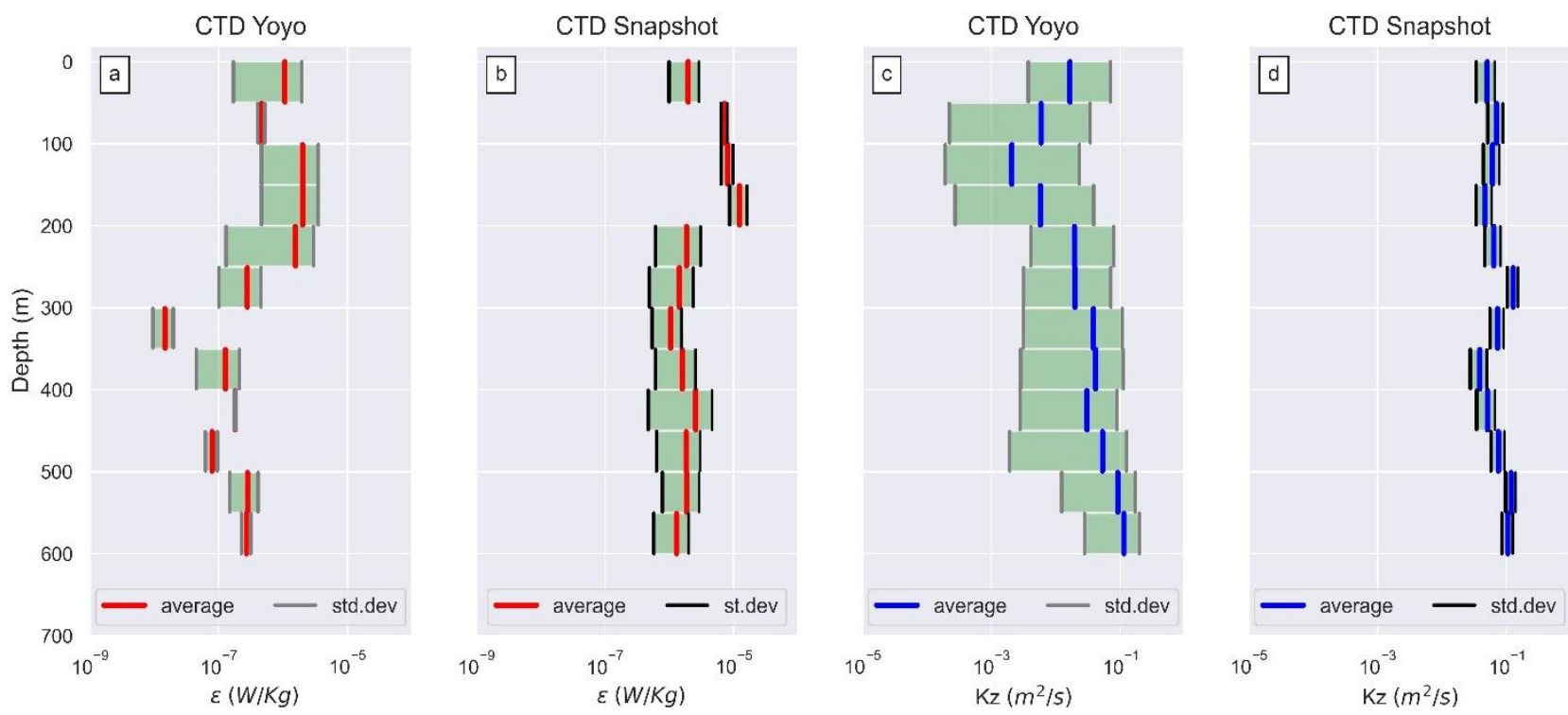

Figure 9. Comparison mean values and standard deviation of energy dissipation (a) CTD Yoyo, (b) CTD Snapshot and vertical diffusivity (c) CTD Yoyo, (d) CTD Snapshot

process, the tidal pattern that is not strong is increasingly invisible. Waves that form below the surface of the water are internal waves. Internal waves that have the same period as the tidal period are called internal tides. In addition, Solar Semi Annual (SSA) and Solar Annual (SA) are significant components so that the Lombok Strait is also influenced by seasonal conditions (Abida et al., 2015).
Koch-Larrouy et al. (2007) stated that the internal tide is one of the most significant energies that cause the mixing process in the sea, especially in the thermocline layer. Internal wave interactions can trigger the breaking of the wave and form areas with high shear values and are local so that it can trigger turbulence. This interaction leads to internal wave energy dissipation (Polzin et al., 1997). Internal waves have an essential role in ocean 
Tidal elevation of the Lombok Strait
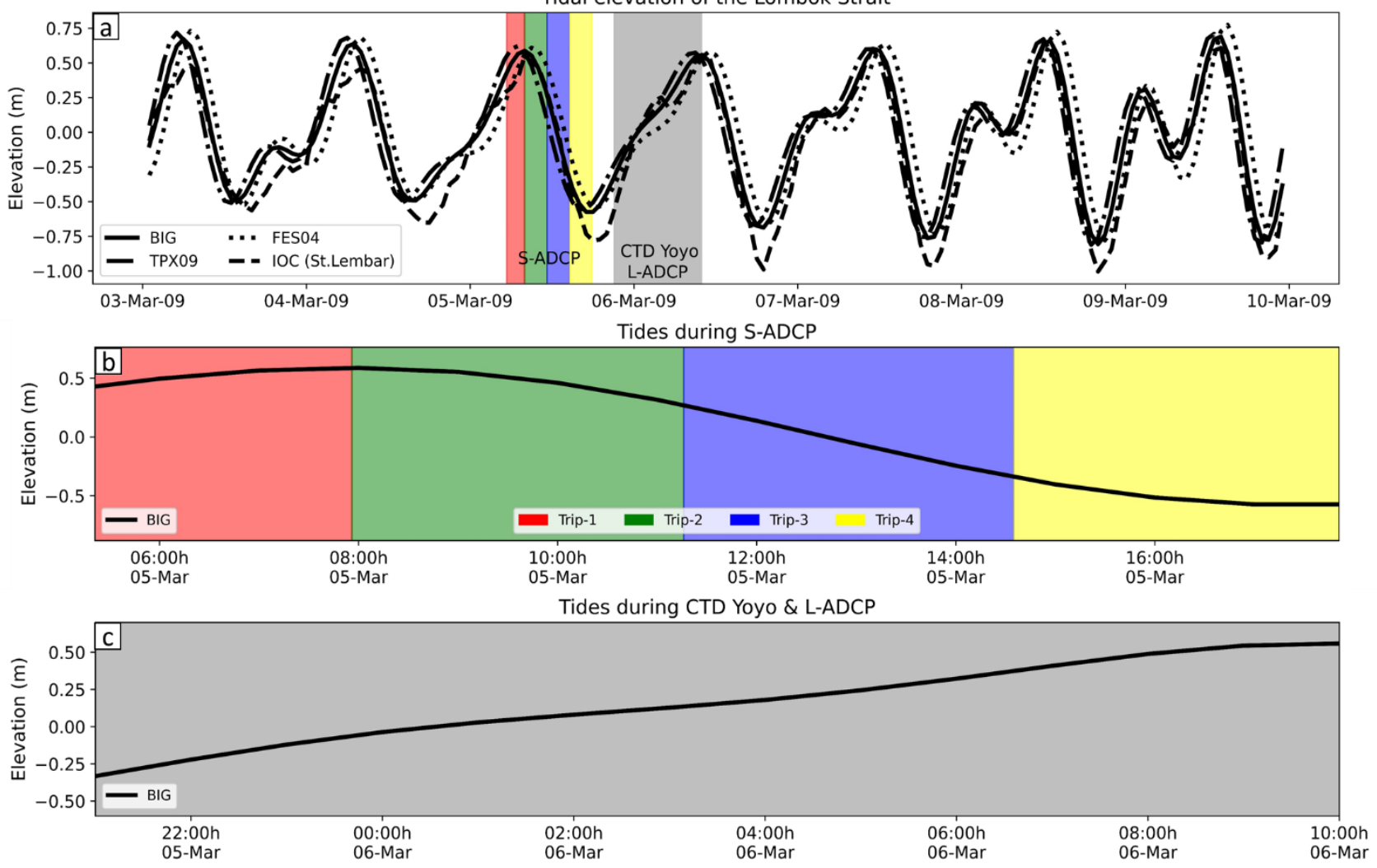

Figure 10. The tidal elevation in the waters of the Lombok Strait (a) 3 - 9 March 2009, (b) a 12 hour period when S-ADCP data was collected, each color represented a trip measuring back and forth between Lombok-Bali-Lombok and (c) 12 hours when data collection for CTD Yoyo and L-ADCP which received 27 replications

thermodynamics. In addition, these internal waves will propagate spatially and will trigger an exchange of energy. This process will result in the transfer of energy from large to small scale (Winters and D'Asaro, 1997).

\section{Ocean current distribution}

S-ADCP data collection in the Lombok Strait canal was carried out back and forth between Lombok Island and Bali Island four times with a duration of about 12 hours. The first collection (trip1) took place between 05:21-07:56, the second (trip2) $08: 01-11: 00$, the third (trip-3) 11:16-14:31 and the fourth (trip-4) 14:36-17:51 local time. The current vector distribution from the results of the 2009 Kaiyo voyage measurement in the Lombok Strait is presented in Figure 11 (a) 29 m, (b) $125 \mathrm{~m}$ and (c) $397 \mathrm{~m}$. The results of the current visualization show that the movement of surface currents is still influenced by winds above the surface. The current vector at a depth of $125 \mathrm{~m}$ corresponds to the water mass characteristics that have been identified, namely the mass of water from ITF that flows from the Northeast to the Southwest. The movement of currents towards the Indian Ocean through the
Makassar Strait then towards the Lombok Strait in the thermocline layer. The current moves towards the Southwest which enters the Lombok Strait from the Northeast after passing through the Makassar Strait.

The S-ADCP on trip-1 (red highlight) occurs when it enters the tide state. The distribution of surface currents seems strong enough to reach a magnitude of $0.6 \mathrm{~m} . \mathrm{s}^{-1}$ with a high enough concentration value on the west side of the Lombok Strait canal with a reasonably constant direction towards the north. At a depth of $125 \mathrm{~m}$, it can be seen in the central region of the strait and the west side, and the current is heading Southwest with an abnormally high value of about $0.5 \mathrm{~m} . \mathrm{s}^{-1}$ even though tides enter from the Indian Ocean. The deep layer (397 $\mathrm{m}$ ) shows a pattern which is quite similar to the current vector on the surface layer, although with a small magnitude, not as significant as the magnitude of the surface layer. On trip-2 (green highlight), the measurement of S-ADCP is in the peak phase and towards low tide. The surface layer shows an irregular current pattern. Although on the west side, it appears to have a reasonably constant value going south with a magnitude in the range of $0.4 \mathrm{~m} . \mathrm{s}^{-1}$. Significant differences were seen in the depth of the thermocline 

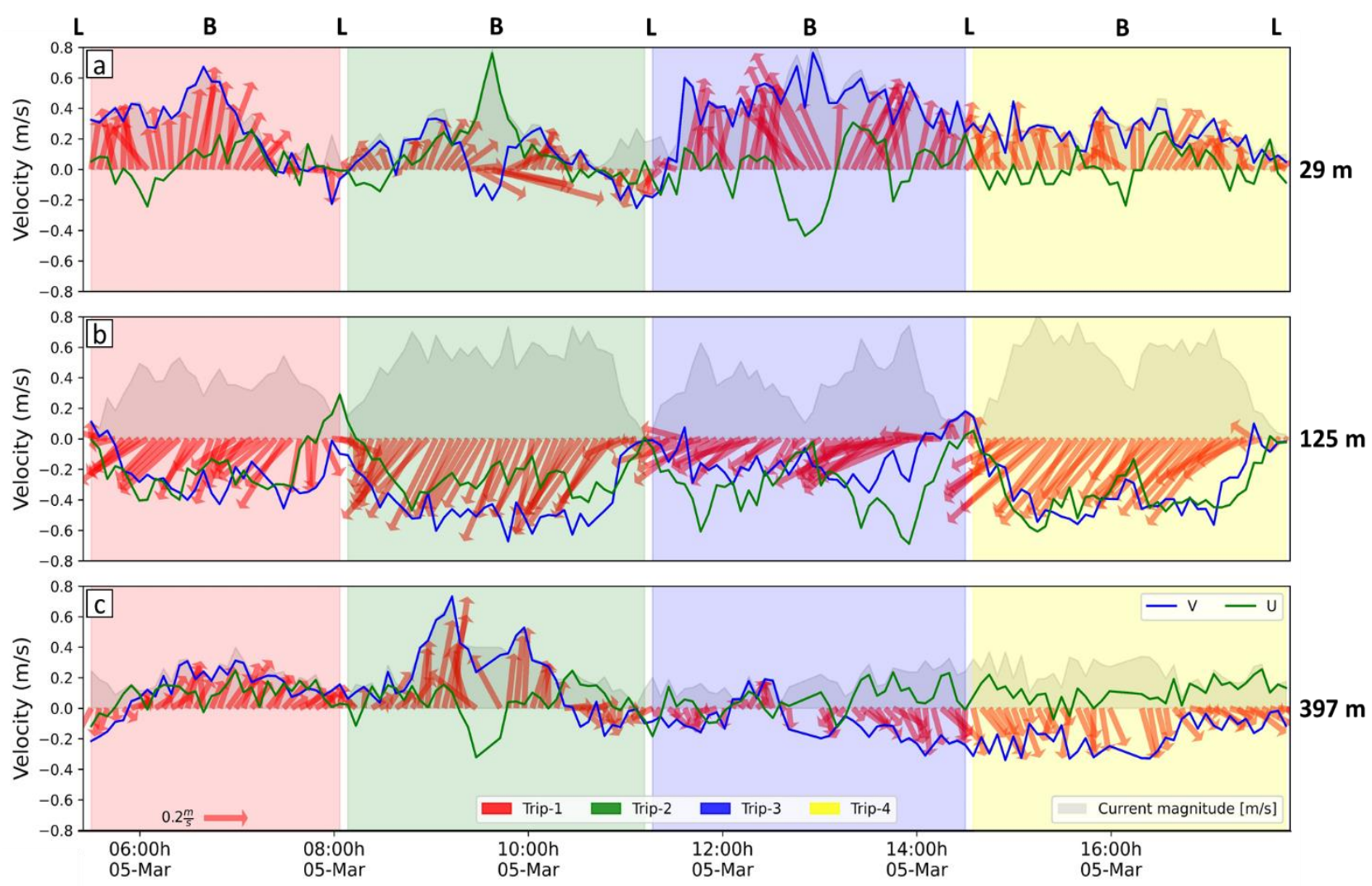

Figure 11. The velocity and direction of ocean current in the Lombok Strait at (a) $29 \mathrm{~m}$, (b) $125 \mathrm{~m}$ and (c) $397 \mathrm{~m}$. The blue line is the meridional current $(\mathrm{V})$ and the green line is the zonal current $(\mathrm{U})$.

layer $(125 \mathrm{~m})$. It can be seen that the current on the west side flows from the northeast to the southwest with a large enough magnitude around $0.7 \mathrm{~m} . \mathrm{s}^{-1}$ and is relatively constant to the middle of the strait. The direction and velocity of the current in the tidal phase differ from the phase towards the tide. In the low tide phase, the current at a depth of the thermocline has a considerable value and a constant direction when compared to the phase towards the tide, especially on the west side. The deep layer has a pattern similar to the surface layer. On the west side, currents are heading south with relatively high values with a magnitude of $0.7 \mathrm{~m} . \mathrm{s}^{-1}$ to the central of the strait. Meanwhile, in the middle of the strait to the east side, the flow is relatively southward with small magnitude.

Measurement trip-3 (blue highlight) at tidal conditions entering the phase towards ebb. The surface layer is dominated by currents heading to the Northwest, North and Northeast which are relatively constant with a minimum magnitude of $0.2 \mathrm{~m} . \mathrm{s}^{-1}$ and a maximum of $0.8 \mathrm{~m} . \mathrm{s}^{-1}$. However, the layer below it, the thermocline layer, also has a strong enough value with the direction of the flow towards the Northwest on the west and central of the strait. Only the eastern side has a small magnitude and does not lead dominantly to the Southwest. ITF flow is still constant in the downward phase, which intensifies the surface layer. The deep layer has a value and direction that is inversely proportional to the surface layer. The east to the middle of the deep layer is a current that tends to the south with a magnitude ranging from $0.4 \mathrm{~m} . \mathrm{s}^{-1}$. The S-ADCP trip-4 (yellow highlight) measures the tidal conditions in the low tide phase. The surface layer has a reasonably constant value with a magnitude between $0.2-0.4$ m.s $\mathrm{s}^{-1}$. In contrast to the surface layer, the thermocline layer reaches a maximum value and is constant on almost all sides pointing to the Southwest with a magnitude of 0.4 $\mathrm{m} . \mathrm{s}^{-1}$ to more than $0.8 \mathrm{~m} . \mathrm{s}^{-1}$. In this phase, the current value of the thermocline layer intensifies and reaches the highest value when compared to other phases. The deep layer also experiences a different direction with the surface layer and in the direction of the thermocline layer towards the dominant south direction with a reasonably constant magnitude in the range $0.2 \mathrm{~m} . \mathrm{s}^{-1}$ to $0.4 \mathrm{~m} . \mathrm{s}^{-1}$. according to the research results of INSTANT (2005) the dominant surface current pattern is southward. This study shows the direction of the dominant surface currents to the north, because when the measurement is in the phase towards the tide, the tidal currents go to Indonesian waters that propagate from the Indian Ocean. 
Mayer and Damm (2012) found jet currents in the layer below the surface layer, namely in the thermocline layer that moves to resemble the western boundary current along the ITF route from the Sulawesi Sea entering the Makassar Strait to exit through the Lombok Strait. This is confirmed by the visible direction in the thermocline layer of current movement from northeast to the southwest when entering the strait. However, in the surface layer, there is a relatively different current pattern, namely, the speed and direction of the current trend to go north. This is due to the influence of the wind and the influence of tidal waves from the Indian Ocean that enter the Lombok Strait. These tidal waves then form an internal wave when the wave passes through the sill (mound on the seabed) when its propagation enters the Lombok Strait (Susanto et al., 2005).

Retrieval of L-ADCP data together with the retrieval of Yoyo CTD data. The distribution profile of zonal current $(\mathrm{u})$ and meridional current $(\mathrm{v})$ components can be seen in Figures 12 (a) and (b). The zonal current velocity component in the surface layer is dominated by currents directed eastward, in the thermocline layer tends to the west, and in the deep layer, there are flows to the east and west. The components of the meridional current velocity in the surface layer are mostly to the north. It is influenced by the tides from the Indian Ocean during the flood phase. In the thermocline layer, the velocity of the meridional currents to the south (southwest) is indicated as the ITF currents carrying water masses from the Pacific Ocean through the Lombok Strait.

The distribution of meridional currents (v) in Figure 12 (b) shows that in general, the currents in the thermocline layer flow to the south. This is in accordance with Wyrtki's (1961) statement that the mainstream of ITF from the Makassar Strait and then out through the Lombok Strait always flows in a dominant direction towards the south throughout the year. In contrast to the thermocline layer, the surface layer flows in the direction of distribution to the north. This causes the surface water mass to move at a slower speed than the water mass in the lower layer because it rubs in different directions. On the surface layer, the value of the meridional current distribution is relatively high pointing north and has a pattern similar to the tidal elevation when collecting L-ADCP data. The surface layer meridional current velocity has the highest value at the time of measurement towards the tide.

This is consistent with the measurement of SADCP data when the phase towards tide, the surface layer appears to have a high value, especially on the west side. The thermocline layer shows a dominant and constant value towards the south, and the flow depth is in accordance with the tidal elevation at the time of data collection. The maximum recorded flow rate of ITF at a depth range of $125 \mathrm{~m}$. The mean value and standard deviation of the current on the S-ADCP for a depth of $29 \mathrm{~m}$ are $0.322 \pm 0.183,125 \mathrm{~m} 0.430$ \pm 0.188 and $397 \mathrm{~m} 0.213 \pm 0.124$

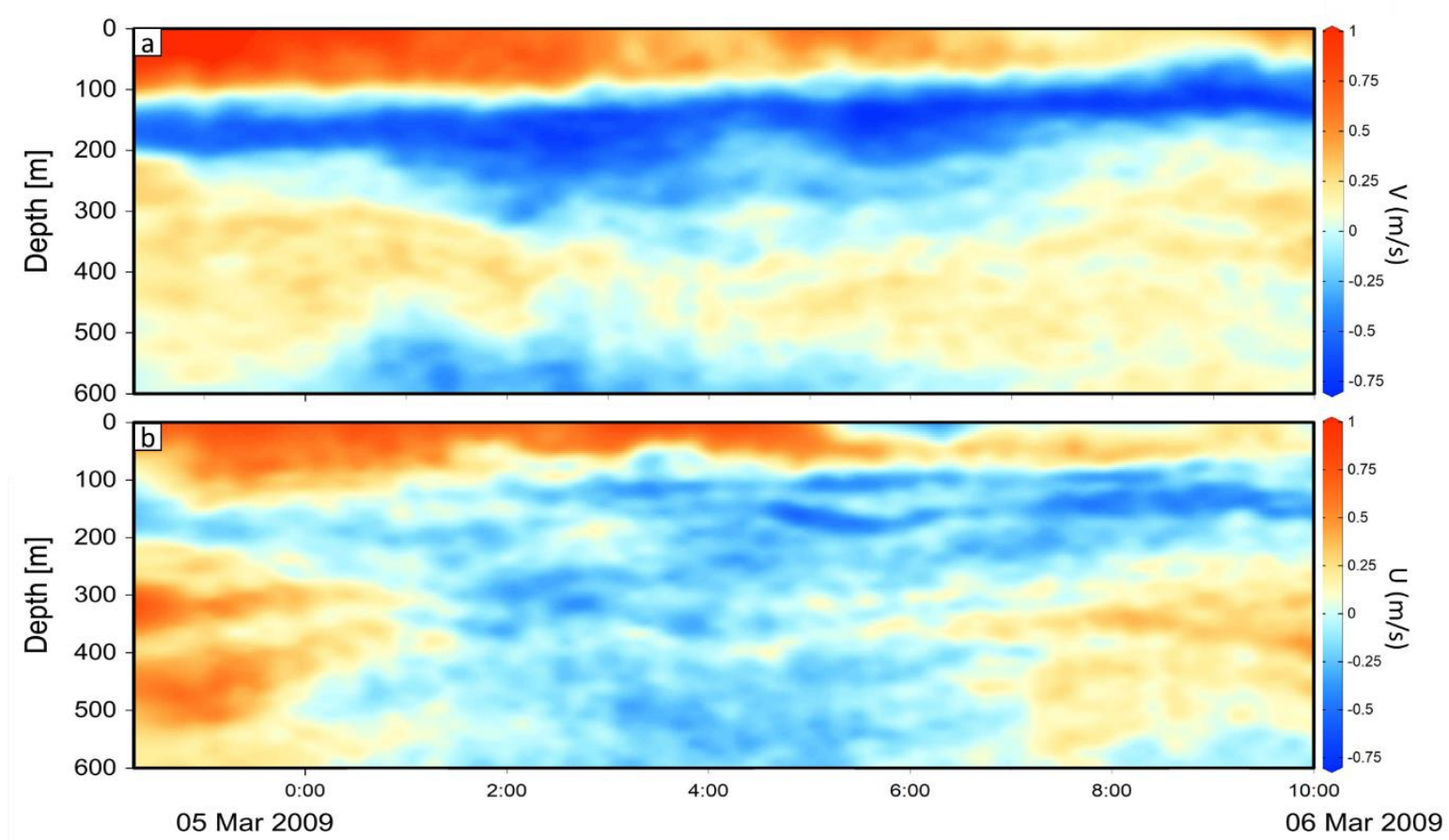

Figure 12. Profile of cross-sectional distribution of time components (a) meridional current $(\mathrm{V})$ and (b) zonal current (U) L-ADCP 


\section{Shear (s) and Richardson (Ri) estimation}

The energy dissipation value in the thermocline layer is higher than that of the mixed layer and the deep layer. There is a high shear value, reaching $0.24-0.92 \times 10^{-2} \mathrm{~s}^{-2}$ and is relatively constant in the thermocline layer (Figure 13). ITF enters Indonesian waters through the sill in the SangiheTalaud archipelago which is then continued to the Makassar Strait. The flow of water masses is then cooled by the fresher surface water masses, which can block the warm surface water masses during the western monsoons (Gordon et al., 2003). As a result, ITF main transport does not occur in the surface layer but the thermocline layer. The higher energy dissipation value implies that shear plays an essential role in controlling turbulence. The Lombok Strait, which is in the form of a narrow canal, causes the flow of ITF water mass (current) entering from the Makassar Strait to become stronger. This is in accordance with the law of mass conservation so that the flow is accelerated. Increasing the shear current has the potential to distort the stability of the water mass leading to the formation of turbulence which results in mixing of water masses. Strong vertical shear in the Lombok Strait is related to the intensification of ITF through the narrow strait which can increase turbulent mixing (Nagai and Hibiya, 2020).

Based on Figure 14, it can be seen from the vertical section that the high Richardson gradient (Ri) values are scattered. However, it is relatively consistently high around the thermocline layer. Thus, the water mass in the area is considered difficult to mix with the depths above and below it. The process of water mass transformation is also influenced by the value of the $\mathrm{Ri}$ in addition to the dynamics of the water mass due to the presence of internal waves. The value of Ri represents the relationship between the effect of water mass stability (density structure effect) represented by the Vaisälä brunt and the mechanical strength of the water mass represented by the shear. Considering that the current measurement in this study is only snap-shot, the Ri vertical profile will be analyzed for its vertical dynamics to identify the layers that are suspected of having the potential to occur turbulence which can trigger water mass mixing.

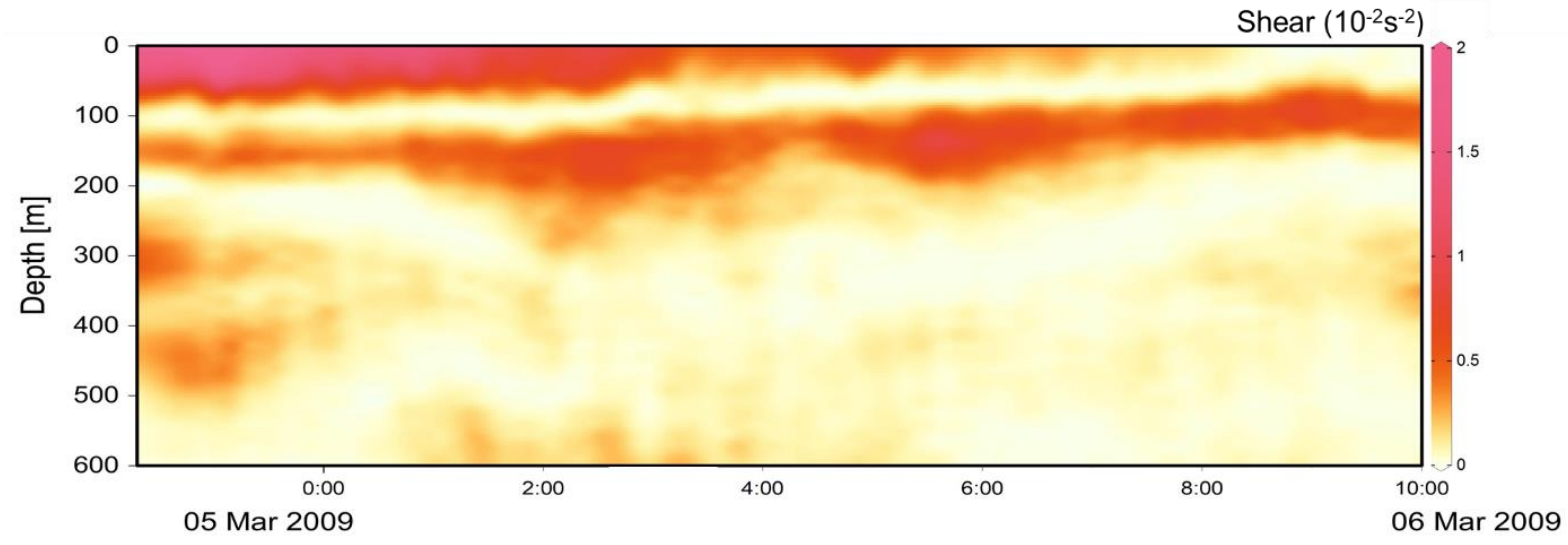

Figure 13. Shear (s) value cross-sectional profile in the waters of the Lombok Strait

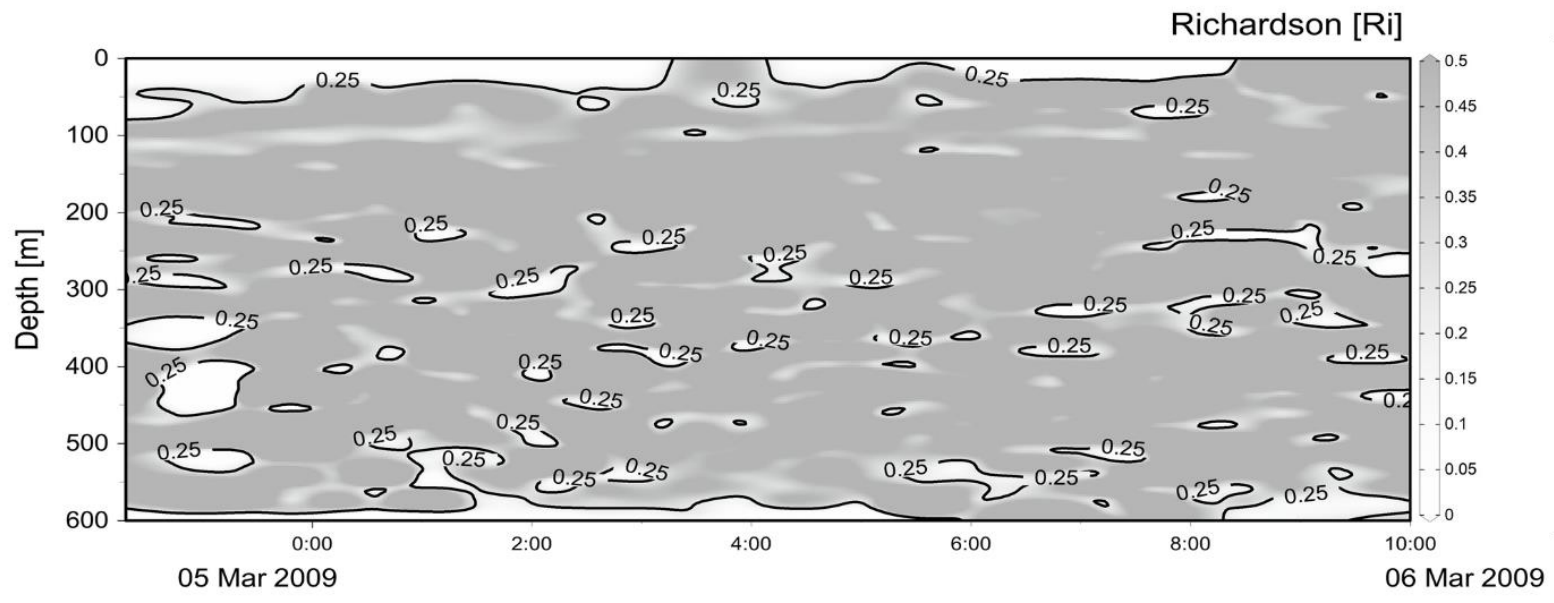

Figure 14. Richardson gradient value $(R i)$ cross-sectional profile in the waters of the Lombok Strait 
Future research will be better with more comprehensive data. This study uses a critical value of 0.25 . If the Ri value is $<0.25$, then the water mass stratification is still considered low. Meanwhile, the value of $\mathrm{Ri}>0.25$ describes well-stratified waters or can be expressed as a stable water mass. According to Pond and Pickard (1983), empirically when Ri> 0.25 , turbulence cannot be formed even though there is a vertical velocity gradient. Thus, the vertical distribution of the mass field, which is related to the variation in the viscosity of the water mass will also determine the mechanical turbulence modifications that arise

\section{Conclusion}

In the Lombok Strait, four types of water masses were identified, Javanese seawater mass, mixed water mass (Java Sea and ITF), NPSW water mass (high salinity) and NPIW water mass (low salinity) was clearly visible in all replication data. It can be seen that there is a transformation of the seawater mass with decreasing and increasing salinity values. The Lombok Strait has high energy dissipation and vertical diffusivity values. The average values for energy dissipation and vertical diffusivity for each layer and replication were $5.73 \times 10^{-7} \mathrm{WKg}^{-1}$ and $3.67 \times 10^{-2} \mathrm{~m}^{2} \mathrm{~s}^{-1}$ for CTD Yoyo and $2.25 \times 10^{-6}$ $\mathrm{WKg}^{-1}$ and $7.38 \times 10^{-2} \mathrm{~m}^{2} \mathrm{~s}^{-1}$ for CTD Snapshot. These categorized as areas that have a strong turbulent mixing value. The value obtained is greater than the open ocean and straits in other studies. The high energy dissipation value in the thermocline layer can be caused by the Lombok Strait, which has internal waves and intensification of ITF (shear) because it is in the middle of a narrow strait. The Ri value tends to be small on the surface and deep layers, while the thermocline layer tends to be strong because this layer is well stratified.

\section{Acknowledgements}

The authors would like to thank the Japan Agency Marine-Earth Science and Technology (JAMSTEC) and Agency for the Assessment and Application of Technology (BPPT), Indonesian Navy Hydrographic and Oceanographic Center (PUSHIDROSAL) which has allowed the use of survey data, Dr. Adi Purwandana from Research Center for Oceanography (P2O-LIPI) for his input and suggestions. And reviewers for careful review and favorable comments and suggestions, which help an improving the paper.

\section{References}

Abida, R.F., Pranowo, W.S., Pratomo, Y. \& Kisnarti, E.A., 2015. Identifikasi komponen harmonik di Selat Lombok berdasarkan data arus time series. Depik, 4(1): 24-32. doi: 10.13170/ depik.1.1.2361

Atmadipoera, A., Molcard, R., Madec, G., Wijffels, S., Sprintall, J., Koch-Larrouy, A., Jaya, I. \& Supangat, A. 2009. Characteristics and variability of the Indonesian throughflow water at the outflow straits. Deep Sea Res., 56: 19421954

Atmadipoera, A.S. \& Hasanah, P., 2017. Karakteristik Dan Variabilitas ITF Flores Dan Koherensinya Dengan Arus Pantai Selatan Jawa. J. IImu Teknol. Kelaut. Trop. 9(2): 537-556

Delpeche, N.C., Soomere, T. \& Lilover, M.J. 2010. Diapycnal mixing and internal waves in the Saint John River Estuary, New Brunswick, Canada with a discussion relative to the Baltic Sea. Estonian J. Eng., 16(2):157-175

Dillon, T.M. 1982. Vertikal overturns: a comparation of Thorpe and Ozmidov length scale. J. Geophys. Res., 87:9601-9613

Emery, W.J. and R.E. Thomson. 1998. Data Analysis Method in Physical Oceanography. BPC Weatons, Britain, $634 \mathrm{p}$.

Fer, I., Skogseth, R. \& Haugan, P.M. 2004. Mixing of the Storfjorden overflow (Svalbard Archipelago) inferred from density overturns. J. Geophys. Res. 109(C1):1-14 doi: 10.1029/2003JC001968

Galbraith, P.S. \& Kelley, E. 1996. Identifying overturn in CTD profiles. J. Atmos. Ocean. Tech., 13:688702

Gunawan, I., Pranowo, W.S. \& Sukoco, N.B., 2019. Studi Karakteristik Massa Air Laut di Perairan Timur Indonesia dengan Memanfaatkan Data Argo Float. J. Chart Datum, 5(2):130-143. doi: 10.37875/chartdatum.v5i2.151

Gordon, A.L., Susanto, R.D. \& Vranes, K. 2003. Cool Indonesian throughflow as a consequence of restricted surface layer flow. Nature. 425: 824828. doi: $10.1038 /$ nature02038

Gordon, A.L., Sprintall, J., Van Aken, H.M., Susanto, D., Wijffels, S., Molcard, R., Ffield, A., Pranowo, W. \& Wirasantosa, S., 2010. The Indonesian throughflow during 2004-2006 as observed by the INSTANT program. Dyn. Atmospheres Oceans, 50(2): 115-128.

Hao, J., Chen, Y., Wang, F., \& Lin, P. 2012. Seasonal thermocline in the China Seas and northwestern Pacific Ocean. J. Geophys. Res.,117: C02022 
Hatayama T. 2004. Transformation of the Indonesian Throughfow water by vertikal mixing and it relation to tidal generated internal wave. $J$ Oceanogr. 60: 569-585.

Instant. 2005. Ekspedisi INSTANT 2003-2005 Menguak Arus Lintas Indonesia. BRKP-DKP. ISBN: 979-3768-06-1

Kitade, Y., Matsuyama, M. \& Yoshida, J. 2003. Distribution of overturn induced by internal tides and Thorpe scale in Uchiura Bay. J. Oceanograp., 59: 845-850.

Koch-Larrouy, A., Madec, G., Bouruet-Aubertot, P., Gerkema, T., Bessières, L. \& Molcard, R., 2007. On the transformation of Pacific Water into Indonesian Throughflow water by internal tidal mixing. Geophys. Res. Lett. 34: 1-6

Martinez, D.M.V., Schettini, E.B.C. \& Silvestrini, J.H., 2006. The influence of stable stratification on the transition to turbulence in a temporal mixing layer. J. Braz. Soc. Mech. Sci. \& Eng. XXVIII(2): 242-252.

Mayer, B. \& Damm, P.E. 2012. The Makassar Strait throughflow and its jet. J. Geophys. Res., 117(C07020): 1-14. doi: 10.1029/2011JCO 07809

Nagai, T. \& Hibiya, T. 2015. Internal tides and associated vertical mixing in the Indonesian archipelago. J. Geophys. Res. 120: 3373-3390. doi: 10.1002/2014JC010592

Nagai, T., Hibiya, T. \& Bouruet-Aubertot, P. 2017. Nonhydrostatic simulations of tide-induced mixing in the Halmahera Sea: A possible role in the transformation of the Indonesian Throughflow waters. J Geophys Res: Oceans, 122: 8933-8943.

Nagai, T., \& Hibiya, T. 2020. Combined effects of tidal mixing in narrow straits and the Ekman transport on the sea surface temperature cooling in the southern Indonesian seas. J. Geophys. Res., 125 (11): e2020JC016314. doi: 10.102 9/2020JC 016314

Nagai, T., Hibiya, T., \& Syamsudin, F. 2021. Direct estimates of turbulent mixing in the Indonesian archipelago and its role in the transformation of the Indonesian throughflow waters. Geophys Res Lett, 48: e2020GL091731. doi: 1029/20 20GL091731

Park, Y.H., Fuda, J.L., Durand, I. \& Garabato, A.C.N., 2008. Internal tides and vertical mixing over the
Kerguelen Plateau. Deep Sea Research Part II: Topical Studies in Oceanography, 55: 582-593.

Polzin, K.L., Toole, J.M., Ledwell, J.R. \& Schmitt, R.W.1997. Spatial variability of turbulent mixing in the Abyssal Ocean. Science, 276: 93-96.

Pond, S. \& Pickard, G.L. 1983 Introductory Dynamical Oceanography Ed ke-2 (Oxford: Pergamon Press)

Purwandana A, Mulia P, dan Agus S. A. 2014. Distribusi Percampuran Turbulen di Perairan Selat Alor. Ilmu Kelautan: Indonesian Journal of Marine Science, 19(1): 43-54. doi: 10.14710/ ik.ijms.19.1.43-54

Purwandana, A., Cuypers, Y., Bouruet-Aubertot, P., Nagai, T., Hibiya, T. \& Atmadipoera, A.S. 2020. Spatial structure of turbulent mixing inferred from historical CTD datasets in the Indonesian seas. Prog. Oceanogr., 184: 102312. doi: 10.1016/j.pocean.2020.102312

Robertson, R. \& Ffield, A. 2005. M2 baroclinic tides in the Indonesian Seas. Oceanography, 18:62-73.

Siregar, S.N., Sari, L.P., Purba, N.P., Pranowo, W.S. \& Syamsuddin, M.L. 2017. Pertukaran massa air di Laut Jawa terhadap periodisitas monsun dan Arlindo pada tahun 2015. Depik, 6(1): 44-59 doi: 10.13170/depik.6.1.5523

Stansfield, K., Garrett, C. \& Dewey, R. 2001. The probability distribution of the Thorpe displacement within overturns in Juan de Fuca Strait. J. Phys. Oceanogr. 31: 3421

St. Laurent, L. C., Simmons, H. L., \& Jayne, S. R. 2002. Estimating tidally driven mixing in the deep ocean. Geophysi Res Lett, 29(23): 21.1-21.4. doi: 10.1029/2002GL015633

Susanto, R.D., Mitnik, L. \& Zheng, A., 2005. Ocean internal waves observed in the Lombok Strait. Oceanography, 18: 80-87.

Thorpe, S.A. 1977. Turbulence and mixing in a Scottish Loch. Philosophical Transactions of the Royal Soc. London Ser. A, 286: 125-181 doi: 10.1098/rsta.1977.0112

Winters, K.B. \& D'Asaro, E.A. 1997. Direct simulation of internal wave energy transfer. J. Phys. Oceanogr. 27:1937-1945. doi: 10.1175/15200485(1997)027<1937:DSOIWE>2.0.C0;2

Wyrtki, K. 1961. Physical Oseanography of the Southeast Asian Waters. Naga Report (2). Scripps Institution of Oceanography, The University of California, La Jolla, California, 195p 